\title{
Advancing the interdisciplinary dialogue on climate justice
}

\author{
Dominic Roser $^{1}$ - Christian Huggel ${ }^{2}$ • \\ Markus Ohndorf ${ }^{3} \cdot$ Ivo Wallimann-Helmer $^{2}$
}

Received: 20 August 2015 / Accepted: 26 October 2015 / Published online: 18 November 2015

(C) Springer Science+Business Media Dordrecht 2015

Climate change is an extraordinary, multi-faceted challenge for mankind and the scale of the challenge is reflected in the breadth and depth of issues of justice it confronts us with (Gardiner et al. 2010). First of all, given the long time spans involved, this includes questions of intergenerational justice (Page 2007): Since a large share of the effect of present emissions will only arise after a significant time lag, it is necessary to consider what type and level of climate actions we owe our descendants. Such a discussion on intergenerational justice necessitates, in turn, extensive debates about risk: Given that there is and will always remain significant scientific uncertainty about the precise future effect of present emissions, determining appropriate margins of safety is crucial (Gardiner 2006; Hartzell-Nichols 2013). Of course, our descendants are not the only relevant stakeholder in these debates: Effects of climate change on the present generation, on animals, and on the rest of nature are grounds for climate action as well (Palmer 2011; Nolt 2011). Another issue of concern is rather about justice within the present generation, as decisions to be made not only involve the overall amount of climate action, but they also need to answer the question on how to split up the burden of taking this action (Caney 2012; Miller 2009). Given that emissions do not respect borders, this means allocating responsibility for climate action on a global scale. Seeking global justice in mitigation, adaptation, and loss and damage is particularly relevant given that many of the more vulnerable countries have comparatively lower (historical and current) per capita emissions and lower capacity to address the problem. While these larger questions of intergenerational and intragenerational justice make up the core of the ethical challenge of climate change, climate change brings up a host of further ethical issues, for example moral aspects of policy instrument choice (such as population control, market measures, or lifestyle changes),

This article is part of a Special Issue on "Climate Justice in Interdisciplinary Research" edited by Christian Huggel, Markus Ohndorf, Dominic Roser, and Ivo Wallimann-Helmer.

Dominic Roser

dominic.roser@law.ox.ac.uk

1 University of Oxford, Oxford, UK

2 University of Zurich, Zürich, Switzerland

3 ETH Zurich, Zürich, Switzerland 
the ethics of science communication, or issues of participation and democratic accountability in decision-making about climate action (Caney and Hepburn 2011; Keohane et al. 2014; Roser and Seidel 2015; Wallimann-Helmer 2013, 2015a).

Given the sheer scale of the risks and burdens involved, in particular for the most vulnerable, climate justice in the global dimension is obviously of high relevance. But global justice is not only relevant for its own sake, it is also instrumental for achieving the societal and global consensus necessary for a climate policy agreement which is intergenerationally just (Miller 2009): Only policy outcomes that are perceived to globally distribute burdens in a way that is at least minimally fair stand a chance of being accepted. For the new climate agreement currently under negotiation, questions of global justice may become a crucial aspect and - given the diverging positions and perspectives of different groups of countries - possibly a stumbling block.

The debate on climate justice is not only booming because of its practical relevance but also because of its overwhelming difficulty. It involves a whole set of novel issues that humanity is inexperienced in evaluating, such as intersecting questions of long time periods and large spatial scales, decision-making under extensive scientific uncertainty, or a thoroughly changed relationship between humans and non-human nature (Gardiner 2011). One aspect that makes debates about climate justice particularly challenging is their close interdependency with fastchanging scientific developments. A large part of the climate justice debate arises among natural and social scientists when they are prompted by their results to face inescapable questions of justice. Another part of the debate originates among moral and political philosophers aiming to apply or adapt their existing theories of justice to the new challenge of climate change. However, all too often, neither the natural and social scientists from the empirical side nor the moral and political philosophers from the normative side have a good grasp of each other's work. This insight was the starting point for a workshop of the Network for Interdisciplinary Climate Research at the University of Zurich and ETH Zurich ${ }^{1}$ which had the goal to interweave empirical and normative perspectives on climate justice. ${ }^{2}$ This workshop provided the foundation for the present special issue. Some of the ideas elaborated here were originally discussed on this occasion, while other contributions were invited.

Given the complexity of the problem of climate change, involving natural, political, socioeconomic, and value systems, any systematic response to this problem must draw on a variety of research disciplines. While at first, it was only a topic for climate (and closely related) sciences, social sciences have become extensively involved in the debate more recently. With growing knowledge in all of these scientific disciplines, it is not only important to promote an open dialogue across disciplinary boundaries, but also to integrate the different perspectives. If research in the various disciplines is to effectively and reliably inform political decisions and societal strategies to deal with climate change, we need to go beyond common but overly narrow conceptions of scientific disciplines (Hirsch Hadorn et al. 2006).

Yet, to effectively inform real-world climate policy, an interdisciplinary dialogue exclusively involving the natural and social sciences is insufficient. Policy choice is not only driven by questions such as "What is the current situation?" And "What are the outcomes for the climate and mankind given specific actions (or inaction)?" Choosing the appropriate response

\footnotetext{
$\overline{1}$ http://www.climate-network.uzh.ch/

${ }^{2}$ It should be noted that we use "empirical" here in a very liberal sense, as the opposite of "normative". The contrast we want to draw is between research that answers "is"-questions (including "is"-questions about the law) and research that answers "ought"-questions. While the latter often goes under headings such as ethics, moral and political philosophy, or justice research, the former goes under headings such as empirical research or positive science (or also descriptive or factual research; or sometimes merely science simpliciter).
} 
to climate change also requires determining which of these futures is to be preferred. The interdisciplinary dialogue hence must also involve normative insights. Such insights have been examined and debated in the field of climate justice, or climate ethics. This is a thriving area of research and the IPCC has given it prominent and extensive attention for the first time in its fifth Assessment Report (AR5). Indeed, given the limited interaction of research strands represented in the different chapters of this report, the question arises on how to strengthen the dialogue between scholars from the natural and social sciences on the one hand and moral and political philosophers on the other hand.

Considerations of justice in the context of climate change are not just an abstract academic endeavor. For over 20 years, parties to the UN Framework Convention on Climate Change (UNFCCC) have debated how to operationalize its normative principles of inter- and intragenerational equity. Within these debates, the underlying conflicts of interests between the participants have become obvious, as showcased in the negotiations on 'historical responsibility', which were marked by the dispute between developed and developing countries (Friman and Hjerpe 2015). While one might be tempted to reduce these debates to a matter of pure politics, arguments related to equity play an important role in the establishment of country positions. Hence, while at first sight, negotiations seem to primarily reflect political bargaining, the quasi-omnipresence of equity considerations within this process hints at the fact that the normative dimension is intrinsic to the political process (Okereke 2010). In fact, as Shue (1992) puts it, considering justice within climate policy is unavoidable and a deeper understanding of justice-related issues is necessary to come to an agreement that is normatively and politically acceptable.

Given the complexity of the climate change problem, there is no single issue of 'climate justice', but rather a multi-dimensional challenge for seeking the normatively acceptable. Parks and Roberts (2006), for instance, propose 10 layers of climate justice which need to be addressed within climate policy. Understanding and solving the different justice-related issues, hence necessarily requires the integration of different areas of expertise, which turns 'climate justice' into a formidable challenge for an ongoing interdisciplinary dialogue. Fostering such a dialogue requires thinking in terms of specific problems, but not within the boundaries of disciplinary "home turfs". In this special issue we focus on issues of climate justice in order to promote such a dialogue.

To foster interaction on climate justice between empirical and normative disciplines, this issue takes an unconventional approach. Each subject is addressed by two different papers, with a first paper reflecting findings in the natural or social sciences or law. A second "companion"paper complements the discussion by examining the normative aspects of the problem at hand. While each paper still represents an independent research article in itself, we encouraged the dialogue between the authors of each pair prior to and during the writing process. As the level of interconnection within each pair was left to the authors, the degree of disciplinary interlacing varies among the different contributions. Yet, each pair in this issue displays the open mindset necessary for future interdisciplinary work in the respective field.

Of course, in an exercise such as this special issue the same open mindset is also required on the part of the reviewers, the editors, and ultimately also the reader. As each pair of papers can only touch on some, but not all important aspects in the respective area, we are confident that they serve as valuable contributions for opening up further avenues in the ongoing interdisciplinary dialogue on climate justice. 


\section{Structure of special issue}

This issue not only contributes to long-standing justice debates with new scientific evidence but also reveals and highlights questions of justice and themes that have not received sufficient attention so far. A series of papers first addresses the enormous global mitigation challenge by focusing on carbon budget and burden-sharing approaches as well as on border tax adjustments. Following that, negative impacts of climate change are approached by a number of contributions that analyze whether recent progress in the field of attribution of impacts to anthropogenic climate change can contribute to the justice discussion. Eventually, a series of papers shed light on perspectives and perceptions of various actors, including local communities in various geographical and cultural settings, the general public and developing countries.

\section{The global mitigation challenge}

Based on earlier studies and proposals (e.g. Meinshausen et al. 2009) the IPCC's AR5 assessed the carbon budget of the Earth, with temperature increasing approximately proportionally to the total emitted CO2 (IPCC 2013). Knutti and Rogelj (2015) extend in this issue on the IPCC AR5 and specify a number of critical aspects of the carbon budget which are relevant in the justice discussion. Their argument is that the carbon budget approach has a number of simple but far-reaching implications that so far have not yet appropriately been addressed by policy. The basic message is that climate science is now sufficiently clear about the remaining carbon budget for keeping global warming under certain thresholds of temperature increase (such as $2{ }^{\circ} \mathrm{C}$ ) with a certain probability. This is the basis for passing the ball to climate policy, but also climate justice. The companion paper by McKinnon (2015) in this issue follows exactly this path and outlines the fundamental issues that matter for distributing the remaining carbon budget among countries. McKinnon (2015) analyzes principles of distributive justice concerning the allocation of emission rights and the costs of mitigation. However, she extends the perspective by touching on related justice aspects such as compensation for the harms caused by climate change, introducing considerations of criminal justice into climate debates, and catastrophe ethics. The latter issues are closely tied to discussions breached upon by a number of other contributions to this special issue, such as Mera et al. (2015); Thompson and Otto (2015); Huggel et al. (2015), and Wallimann-Helmer (2015b) (see below).

The question of how to fairly allocate the burden is approached from a more practical perspective in the contributions to this issue by Schuppert and Seidel (2015) as well as Ohndorf et al. (2015). Both papers critically assess budget approaches to allocate and trade emissions. In 2009, assuming the $2{ }^{\circ} \mathrm{C}$ guardrail the German Advisory Council on Global Change (WBGU) developed a cap and trade mechanism which not only describes the necessary emission cuts to keep emissions within the budget to secure the $2{ }^{\circ} \mathrm{C}$ guardrail but also does so in a manner that is perceived to be feasible for all involved parties. In their contribution to this special issue, Schuppert and Seidel (2015) critically assess the proposal by the WBGU. They highlight several normative issues in the WBGU budget approach which should be made more explicit and in some cases revised. Most importantly, they argue that the rationale for calculating the remaining budget should be revised in order to avoid implausible assumptions. Furthermore, they argue that the WBGU proposal is not necessarily linked to equality as the core principle of justice. From the perspective of environmental economics, 
Ohndorf et al. (2015) critically discuss the issues raised by Schuppert and Seidel (2015). They argue that despite its normative flaws the WBGU proposal can serve as an important tool for raising awareness of the necessity to counteract climate change by mitigation efforts. The WBGU approach and budget approaches more generally can serve this goal particularly well because they are easy to understand and try to calculate the remaining emission budget as straightforwardly as possible.

Given how the global community struggles to achieve a coordinated effort and given that few if any countries do their fair share as specified by burden-sharing principles, unilateral climate action becomes an important topic. Unilateral action in turn makes border tax adjustments a relevant issue and this is the topic of the pair of papers by Weber (2015) and Brooks (2015) (both in this issue). They examine the legal and ethical issues implied by this policy instrument. Weber (2015) considers border tax adjustments to be a second-best solution for making progress on climate mitigation measures but the big challenge is the question whether these measures can be implemented such that they do not conflict with the legal framework of the World Trade Organization (WTO). He shows how this is difficult but not impossible, depending on the exact design of the measure and the interpretation of the relevant WTO law. In the companion article, Brooks (2015) critically assesses the premises and conclusions from Weber's paper. He widens the scope to argue that, more generally, strategies based around taxation - such as the Global Resources Dividend, the polluter pays principle and border tax adjustment - are less convincing than they might seem at first sight. For example, carbon taxes might just not be enough to achieve a sustainable future in case polluters with sufficient means simply continue to emit despite facing a price increase for doing so.

\section{Attribution and loss and damage}

Several papers in this issue are concerned with questions of attribution of climate change, and climate change impacts to anthropogenic greenhouse gas emissions. Detection of observed changes and attribution to climate change has a longer tradition in physical climate science. For climate change impacts research this is a more recent field and there is still some way to go to fully clarify methods and the implications of the research (results) (Stone et al. 2013). Also, the dissemination into the larger research community is still underway. One of the important debates emerging from attribution research centers around the question whether attribution, and in particular attribution of extreme weather events, can usefully inform international climate policy, and more generally, whether it can usefully contribute to climate justice debates. Some recent studies (such as Pall et al. 2011) see a role for attribution in debates about adaptation funding, whereas Hulme et al. (2011) and Hulme (2014) strongly argue against this claim. However, with the rise of loss and damage as a policy mechanism, which is increasingly pushed in the international climate negotiations, several contributions in this issue add depth and substance to the emerging debate and examine from different perspectives whether, and to what degree, attribution can have a role in informing or supporting loss and damage policies.

Mera et al. (2015) contribute to this issue with a study on heat waves in California which have a disproportional impact on Latino workers. By means of probabilistic event attribution (PEA) they evaluate to what degree extreme temperatures in California can be attributed to anthropogenic climate change. The case is interesting because it reflects the occurrence of 
injustice within a major GHG emitting country, where a group of people bear a higher burden than others due to their high exposure to high temperatures (as opposed to people working with air-conditioning, for instance). A similar case is analyzed in Huggel et al. (2015) (this issue): indigenous communities in Alaska suffering from coastal erosion and floods. As the authors show, however, the causal relations all the way from anthropogenic climate change with effects on sea ice reduction and thaw of permafrost to observed loss and damage is complex and needs further research.

Thompson and Otto (2015) (this issue) argue from a justice perspective for a role of PEA in loss and damage policy but not in adaptation. They point to the important role of recognition in a reconciliation process as a critical element in the policy negotiations. Extending from current discussions about the role of attribution for adaptation on the one hand, and loss and damage on the other hand, Wallimann-Helmer (2015b) sheds light on this difference from a justice perspective. He argues that the primary concern of a loss and damage policy mechanism should be compensatory justice, including remedial responsibility, corrective liability, and fair remedy. An important aspect in the justice discussion on loss and damage is the distinction between recoverable damage and irrecoverable loss. Examples of irrecoverable loss can be found, for instance, in case of small islands (see Betzold (2015) in this issue), or the Arctic (see Huggel et al. (2015) in this issue) with the loss of land, property and cultural identity which all have implications of justice (see Zellentin (2015) in this issue).

\section{Regional and development perspectives}

Those who live in developing countries are the most vulnerable to the effects of climate change, as underlined not only by scientific evidence but as has also been highlighted in several decisions by the parties to the UNFCCC (cf. (UNFCCC 2011, 2012, 2013; IPCC 2014; UNFCCC 2014). Historical responsibility and considerations of capacity imply a leading role for developed countries in both climate change mitigation and adaptation. However, global climate politics finds itself in a deadlock-like situation. This is not only because it seems difficult to find a compromise between developing and developed countries each insisting on their respective understanding of a just distribution of burdens. But as a number of papers in this issue show, it is also because justice issues concerning developing countries are more complex than they first appear.

Among the countries first and most severely hit by climate impacts are Small Island Developing States (SIDS). Hazardous weather events and slow onset events will put these people at higher risk to face loss and damage, and in extreme cases will make leaving their homeland necessary. In her review article in this issue Betzold (2015) provides an overview of the scientific evidence about obstacles for appropriate adaptation efforts in SIDS. She argues that in order to overcome these obstacles more comparative research to provide communities at local levels with the appropriate understanding and resources to tackle climate impacts is necessary. Zellentin (2015) analyzes in this issue one aspect of the obstacles discussed by Betzold (2015); cultural loss due to disappearing homeland that at least some SIDS will risk. She argues that culture is fundamental for our self-understanding and thus self-respect. Since we all have a right to the social bases of self-respect, the risk of cultural loss due to climate change becomes an issue of justice which needs to be dealt with through appropriate adaptation efforts.

As far as justice in burden-sharing is concerned, the current situation is more complex than is reflected by the simple differentiation between Annex I and Non-Annex I-countries, which 
features in the UNFCCC negotiated in 1992. Many countries which were attributable to the developing world in the early 1990s experienced rapid growth in both economic output and greenhouse gas emissions. Hence, many observers call for these countries to take up some form of reduction commitment in order to resolve the deadlock in the international negotiations which became apparent over the years. Michaelowa and Michaelowa (2015) show in this issue that within the group of emerging economies one can indeed find countries which are either supportive of binding commitments or which started to engage unilaterally in mitigation activities. They plausibly conclude that these developments could provide new dynamics in the international climate negotiations.

\section{The public view and perception}

The complexity and multi-faceted nature of climate change makes it necessary to address the subject by integrating various perspectives not only from the relevant disciplines, but also from different societal actors in different parts of the globe. A main concern for successfully addressing climate change is the divergence between science and the public concerning the understanding of climate change. This divide seems to have grown despite massive efforts of science in communication and outreach (Patt and Weber 2014). The importance of climate change perception by individuals, the public and other agents is undisputed and increasing empirical and theoretical evidence has accumulated (Myers et al. 2013; Capstick et al. 2015).

In the policy discussion, local and indigenous communities have received increasing attention, often in relation to their high vulnerability to climate change. In their contribution to this special issue, Jurt et al. (2015) provide insight into the understanding of climate change of local mountain communities in the Andes of Peru and the Alps of Italy. By means of ethnographic work, they examine two communities who experience glacier retreat, their understanding of themselves as members of particular groups and their position in the world, their view on responsibilities for causing climate change, and their perceptions of possible responses. The views in local communities differ from dominant perspectives on issues such as the role of nature or the appropriateness of local versus global responses to climate change. In the companion paper, Calder (this issue), tackles the hard questions about what to make of the variety of beliefs about climate change in different contexts. He argues that the primary question is not how to fairly deal with differing beliefs but which of these beliefs are ultimately most adequate to reality. The justice implications and perspectives of such perceptions of local communities need to be analyzed in further detail. But without doubt this type of research offered by ethnographic studies has the potential to generate an insight that is highly relevant and able to add important substance and depth to the discussion.

A wide divergence of beliefs about climate change and especially climate justice can not only be found between developing and developed countries but also within developed countries and their political debates. Schmidt and Schäfer (2015) investigate in this issue the diversity of constructions of climate justice in public debates by providing a qualitative analysis of several leading newspapers in the US, Germany and India. They found five different patterns which show the complexity of these constructions and which do not allow for an easy compromise between different countries. Betz (2015) in his contribution to this issue argues that the variety of constructions of climate justice not only displays normative disagreement. In the public there are also disputes about scientific evidence which as such influences understandings of what climate justice could mean. Betz (2015) argues that there 
are good reasons for why a society should mainly engage in evaluative discussions but should not question the scientific bases for these evaluations. However, if there is no societal agreement on whom to count as trustworthy scientific experts for climate research, a society might be right to question the scientific basis for its policy decisions.

\section{Conclusion}

As our experience with this special issue shows, climate change is such a multi-faceted problem that interdisciplinary research is a necessity. This is much more easily said than done. In the course of the publication of this special issue there were many lessons to be learned. First of all we saw how the exchange between our authors allowed them to expand the focus of their respective disciplines. Philosophers considered literature from various fields they would not have touched upon in their usual course of inquiry. Scientists and legal scholars became more sensitive to the normative dimensions and justice-related intricacies involved in their research. This enabled all contributors to open up to different vocabularies and standards of research. At the same time, however, several obstacles to the success of this issue emerged as well. For such an endeavor it is necessary to find researchers who are ready to engage with other disciplines and to take up ideas and comments which at first sight might not seem relevant and out of place from their disciplinary perspective. Due to the special format another challenge was to communicate the interdisciplinary character of this special issue to the reviewers and to put the reviews in context accordingly without risking to diminish the disciplinary quality of contributions. For the guest editors this came with a further challenge. We not only had to become familiar with different disciplinary vocabularies and standards of research but also had to judge the quality and relevance of contributions in the light of our overall aim as well as disciplinary standards of quality.

Taking a step back, it is eye-opening to look at the number of researchers involved in this issue. We would like to thank all our approximately 40 authors (authors of rejected papers included) for the willingness to engage in this unique project. Without their commitment to the aims and their readiness to engage with their companion paper and partners it would have been impossible to reach this result. In the same vein we would like to thank the approximately 50 reviewers. Their biggest challenge was to secure the disciplinary quality of the articles with an eye towards the interdisciplinary subject of the special issue. Due to the special issue's scope and structure the biggest share of contributors and reviewers are philosophers (approx. $30 \%$ ). Another part of contributors and reviewers are geographers (approx. $16 \%$ ), political scientists and climatologists (each approx. $14 \%$ ). Other groups of contributors and reviewers belong to economics (approx. $10 \%$ ), law, sociology and journalism, anthropology and psychology (each approx. $5 \%$ ). Thus, there is a genuine variety of disciplines.

The special format of this issue brings together several disciplines dealing with issues of justice in climate change. While this diversity makes it difficult to reach fully general conclusions about the needs of a future research agenda, there are a certain number of points that can be gleaned. First, we have definitely not reached a 'saturation point' in terms of the interdisciplinary involvement which is necessary for appropriately understanding the challenge of climate change. Second, in order to reach better interdisciplinary results it would not only be necessary to have researchers from different fields engaging with each other as they did in our format with paper pairs but also to conduct more joint research and joint publications. Last but not least, although we have nearly 100 scientists making this interdisciplinary collaboration a 
success we recognize that most contributors and reviewers of this issue are either based in Europe (approx. $70 \%$ ) or the US (approx. $20 \%$ ) while only a few are from other countries and only two researchers are affiliated with a university in a Non-Annex I country. The disproportionally small representation of researchers from Non-Annex I countries in this special issue and in general in climate change research has multiple roots and is a justice issue in itself. The problem and the far-reaching implications have been recognized to a certain extent and efforts are made to improve the situation such as is done in the IPCC AR5. In the field of climate justice, expertise from researchers in developing countries is much needed, and efforts to strengthen local capacities and voices should be a priority of international research and assistance.

Acknowledgments We are very grateful to Gertrude Hirsch Hadorn for her valuable feedback on this introduction and to Daisy Lunn for research assistance. Support by the URPP Ethics of the University of Zurich is gratefully acknowledged.

\section{References}

Betz G (2015) Factual and normative dissent in media debates about climate policy. Clim Chang. doi:10.1007/ s10584-015-1489-9

Betzold C (2015) Adapting to climate change in small island developing states. Clim Chang. doi:10.1007/ s10584-015-1408-0

Brooks T (2015) Climate change justice through Taxation? Clim Chang. doi:10.1007/s10584-015-1496-x

Caney S (2012) Just emissions. Philos Public Aff 40(4):255-300. doi:10.1111/papa.12005

Caney S, Hepburn C (2011) Carbon trading: unethical, unjust and ineffective? R Inst Philos Suppl 69:201-234. doi:10.1017/S1358246111000282

Capstick S, Whitmarsh L, Poortinga W, et al. (2015) International trends in public perceptions of climate change over the past quarter century. Wiley Interdiscip Rev Clim Chang 6:35-61. doi:10.1002/wcc.321

Friman M, Hjerpe M (2015) Agreement, significance, and understandings of historical responsibility in climate change negotiations. Clim Pol 15(3):302-320. doi:10.1080/14693062.2014.916598

Gardiner SM (2006) A core precautionary principle. J Polit Philos 14(1):33-60. doi:10.1111/j.1467-9760.2006. 00237.x

Gardiner SM (2011) A perfect moral storm: the ethical tragedy of climate change. Oxford University Press, Oxford

Gardiner S, Caney S, Jamieson D, Shue H (eds) (2010) Climate ethics: essential readings. Oxford University Press, Oxford

Hartzell-Nichols L (2013) From 'the' precautionary principle to precautionary principles. Ethics, Policy \& Environment 16(3):308-320. doi:10.1080/21550085.2013.844569

Hirsch Hadorn G, Bradley D, Pohl C, Rist S, Wiesmann U (2006) Implications of transdisciplinarity for sustainability research. Ecol Econ 60(1):119-128. doi:10.1016/j.ecolecon.2005.12.002

Huggel C, Stone D, Eicken H, Hansen G (2015) Potential and limitations of the attribution of climate change impacts for informing loss and damage discussions and policies. Clim Chang. doi:10.1007/s10584-0151441-z

Hulme M (2014) Attributing weather extremes to "climate change" a review. Prog Phys Geogr 499-511. doi:10. $1177 / 0309133314538644$

Hulme M, O'Neill SJ, Dessai S (2011) Is weather event attribution necessary for adaptation funding? Science 334:764-765. doi: $10.1126 /$ science. 1211740

IPCC (2013) Climate change 2013: the physical science basis. Contribution of working group I to the fifth assessment report of the intergovernmental panel on climate change. Cambridge University Press, Cambridge

IPCC (2014) In: Field CB, Barros VR, Dokken DJ, Mach KJ, Mastrandrea MD, Bilir TE, Chatterjee M, Ebi KL, Estrada YO, Genova RC, Girma B, Kissel ES, Levy AN, MacCracken S, Mastrandrea PR, White LL (eds) Climate change 2014: impacts, adaptation, and vulnerability. part a: global and sectoral aspects. contribution of working group II to the fifth assessment report of the intergovernmental panel on climate change. Cambridge University Press, Cambridge 
Jurt C, Burga M, Vicuña L, Huggel C, Orlove B (2015) Local perceptions in climate change debates: insights from case studies in the Alps and the Andes. Clim Chang. doi:10.1007/s10584-015-1529-5

Keohane R, Lane M, Oppenheimer M (2014) The ethics of scientific communication under uncertainty. Pol Phil Econ 13(4):343-368. doi:10.1177/1470594X14538570

Knutti R, Rogelj J (2015) The legacy of our CO2 emissions: a clash of scientific facts, politics and ethics. Clim Chang. doi:10.1007/s10584-015-1340-3

McKinnon C (2015) Climate justice in a carbon budget. Clim Chang. doi:10.1007/s10584-015-1382-6

Meinshausen M, Meinshausen N, Hare W, Raper SCB, Frieler K, Knutti R, Frame DJ, Allen MR (2009) Greenhouse gas emission targets for limiting global warming to $2^{\circ} \mathrm{C}$. Nature 458:1158-1162. doi:10.1038/ nature 08017

Mera R, Massey N, Rupp DE, Mote P, Allen M, Frumhoff PC (2015) Climate change, climate justice and the application of probabilistic event attribution to summer heat extremes in the California central valley. Clim Chang. doi:10.1007/s10584-015-1474-3

Michaelowa K, Michaelowa A (2015) Do rapidly developing countries take up new responsibilities for climate change mitigation? Clim Chang. doi:10.1007/s10584-015-1528-6

Miller D (2009) Global justice and climate change: how should responsibilities be distributed? Parts I and II. Tanner Lectures on Human Values 28:119-156

Myers TA, Maibach EW, Roser-Renouf C, et al. (2013) The relationship between personal experience and belief in the reality of global warming. Nat Clim Chang 3:343-347. doi:10.1038/nclimate1754

Nolt J (2011) Nonanthropocentric climate ethics. Wiley Interdiscip Rev Clim Chang 2(5):701-711. doi:10.1002/ wcc. 131

Ohndorf M, Blasch J, Schubert R (2015) Emission budget approaches for burden sharing: some thoughts from an environmental economics point of view. Clim Chang. doi:10.1007/s10584-015-1442-y

Okereke C (2010) Climate justice and the international regime. WIREs Clim Change 1:462-474. doi:10.1002/ wcc. 52

Page EA (2007) Climate change, justice and future generations. Edward Elgar Publishing, Cheltenham

Pall P, Aina T, Stone DA, et al. (2011) Anthropogenic greenhouse gas contribution to flood risk in England and Wales in autumn 2000. Nature 470:382-385. doi:10.1038/nature09762

Palmer C (2011) Does nature matter? The place of the non-human in the ethics of climate change. In: Arnold D (ed) The ethics of global climate change. Cambridge University Press, Cambridge, pp. 272-291

Parks B, Roberts JT (2006) Environmental and ecological justice. In: Betsill MM, Hochstetler K, Stevis D (eds) International environmental politics. Basingstoke, Palgrave Macmillan, pp. 329-360

Patt AG, Weber EU (2014) Perceptions and communication strategies for the many uncertainties relevant for climate policy. Wiley Interdiscip Rev Clim Chang 5:219-232. doi:10.1002/wcc.259

Roser D, Seidel C (2015) Ethik des klimawandels: eine einführung. Wissenschaftliche Buchgesellschaft, Darmstadt

Schmidt A, Schäfer MS (2015) Constructions of climate justice in German, Indian and US media. Clim Chang. doi:10.1007/s10584-015-1488-x

Schuppert F, Seidel C (2015) Equality, justice and feasibility: an ethical analysis of the WBGU's budget approach. Clim Chang. doi:10.1007/s10584-015-1409-z

Shue H (1992) The unavoidability of justice. In: Hurrell A, Kingsbury B (eds) International politics of the environment: actors interests and institutions. Clarendon Press, Oxford

Stone D, Auffhammer M, Carey M, et al. (2013) The challenge to detect and attribute effects of climate change on human and natural systems. Clim Chang 121:381-395. doi:10.1007/s10584-013-0873-6

Thompson A, Otto FEL (2015) Ethical and normative implications of weather event attribution for policy discussions concerning loss and damage. Clim Chang. doi:10.1007/s10584-015-1433-z

UNFCCC (2011) Report of the Conference of the Parties on its sixteenth session, held in Cancun from 29 November to 10 December 2010: Part Two: Action taken by the Conference of the Parties at its sixteenth session, FCCC/CP/2010/7, March 15

UNFCCC (2012) A literature review on the topics in the context of thematic area 2 of the work programme on loss and damage: a range of approaches to address loss and damage associated with the adverse effects of climate change, FCCC/SBI/2012/INF14, Nov. 15

UNFCCC (2013) Non-economic losses: technical paper, FCCC/TP/2013/2, Oct. 9.

UNFCCC (2014) Report of the conference of the parties on its nineteenth session, held in Warsaw from 11 to 23 November 2013: Part two: Action taken by the Conference of the Parties at its nineteenth session, FCCC/CP/ 2013/10, Jan 31

Wallimann-Helmer I (2013) The republican tragedy of the commons: the inefficiency of democracy in the light of climate change. Ancilla Iuris 1-14 
Wallimann-Helmer I (2015a) The liberal tragedy of the commons: the deficiency of democracy in a changing climate. In: Birnbacher D, Thorseth M (eds) The politics of sustainability. Philosophical Perspectives. Routledge, New York, pp. 20-35

Wallimann-Helmer I (2015b) Justice for climate loss and damage. Clim Chang. doi:10.1007/s10584-015-1483-2

Weber RH (2015) Border tax adjustment - legal perspective. Clim Chang. doi:10.1007/s10584-015-1414-2

Zellentin A (2015) Climate justice, small island developing states \& cultural loss. Clim Chang. doi:10.1007/ s10584-015-1410-6 